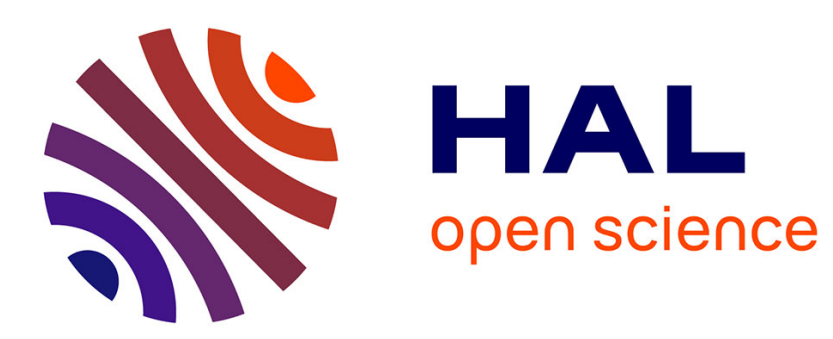

\title{
Allowing for the projective dimension of agency in analysing alternative food 1 networks
}

\author{
Ronan Le Velly
}

\section{To cite this version:}

Ronan Le Velly. Allowing for the projective dimension of agency in analysing alternative food 1 networks. Sociologia Ruralis, 2019. halshs-02081399

\section{HAL Id: halshs-02081399 \\ https://shs.hal.science/halshs-02081399}

Submitted on 27 Mar 2019

HAL is a multi-disciplinary open access archive for the deposit and dissemination of scientific research documents, whether they are published or not. The documents may come from teaching and research institutions in France or abroad, or from public or private research centers.
L'archive ouverte pluridisciplinaire HAL, est destinée au dépôt et à la diffusion de documents scientifiques de niveau recherche, publiés ou non, émanant des établissements d'enseignement et de recherche français ou étrangers, des laboratoires publics ou privés. 
1 Allowing for the projective dimension of agency in analysing alternative food networks

3

4

Ronan Le Velly

UMR Innovation, Univ. Montpellier, Cirad, Inra, Montpellier SupAgro, Montpellier, France

2 place Viala, 34060 Montpellier, France

7 levelly@supagro.fr

8

9

To be published in Sociologia ruralis

10 
11 Allowing for the projective dimension of agency in analysing alternative food networks

\section{Abstract}

This article argues for including the projective dimension of agency in research into alternative food networks. Starting from a review of the literature, I show that referring to the notion of project is useful to answer the questions raised by the use of the term "alternative" and to reinforce analyses of hybridisation and conventionalisation processes. I argue that alternative food networks are characterised by a "promise of difference" in the projects of the actors who promote them. To clarify this notion of project, I rely on the work of French sociologists concerning the creation of "organised action". I posit that taking account of the project amounts to recognising human beings' abilities to imagine and to construct new collectives such as those that are studied in research into alternative food networks. I also underscore the need to envision the project not as a clear determinant of action, but rather as a fuzzy landmark, meaning that negotiation and arbitration are required to set the rules involved in its implementation.

\section{Key words}

Agency, Alternative food networks, Conventionalisation, Fair trade, Food utopias, Hybridisation

\section{Introduction}

Even though alternative food networks are currently a dynamic field of rural studies research (Goodman et al. 2012), the very use of the term "alternative" continues to cause discomfort. For example, whereas the subtitle of their book explicitly talks about "exploring alternatives", Moya Kneafsey and her co-authors justify themselves by explaining that they see this term as a "useful shorthand" (Kneafsey et al. 2008, p. 30). Other authors remind their readers that "alternative" as a concept is problematic and apologise for sticking to it by explaining that it is the term adopted in other articles (Milestad et al. 2010). The reasons for this discomfort are well known. Alternative and conventional food networks are not separate worlds, functioning in radically different ways (Hinrichs 2003, Sonnino and Marsden 2006). Alternative 
initiatives deserve to be analysed as "hybrid spaces" involving actors and infrastructures of the conventional networks (Ilbery and Maye 2005). Some of these initiatives also tend to adopt a portion of the ways in which conventional food systems function, a trend that has been summed up by the catchword "conventionalisation" (Guthman 2004) and has suggested sorting alternative food networks according to their levels of alternativeness (Watts et al. 2005). On the basis of these findings other researchers even call for dropping and replacing the notions of "alternative" and "conventional". According to Larsh Maxey, thinking in terms of "hybrid spaces" is not enough. This can leave "alternative' and 'conventional' food intact, as distinct entities with distinct logics and implications" (Maxey 2007, p. 58). To avoid this danger of essentialisation, Maxey recommends speaking of "sustainable food" instead of “alternative food". Henk Renting, Markus Schermer, and Adanella Rossi argue that "the main shortcoming of the alternative food network concept is that it has no clear normative content of its own, since it is ultimately defined in terms of its distinction from 'mainstream' food networks" (Renting et al. 2012, p. 291). They therefore claim it would be more appropriate to speak of "civic food networks" and study the place of civil society in food system governance. Amanda DiVito Wilson (2013) argues similarly that even studying levels of alternativeness remain unsatisfying, as this relies on abstract and fuzzy notions of alternative and conventional. She proposes accordingly to call the initiatives known up to now as "alternative" "autonomous food spaces" and to study how these initiatives build non-capitalist and non-market exchanges.

Should these authors' reluctance to use the term "alternative" be shared? The argument that I shall defend is that introducing the notion of a "project" offers a way out of this discomfort. More fundamentally, I shall posit that taking account of the project provides a solid theoretical foundation for using the term "alternative" and reinforces analysis of the phenomena of hybridisation and conventionalisation.

The first part of this article will explain the circumstances in which the term "alternative" has been used in rural studies and the reasons why its use has prompted questions. I shall then advance the idea that explicitly taking account of alternative food network proponents' projects (plans, reasons and aims) makes it possible to answer these questions. Fair trade, organic agriculture, and short food supply chains can be analysed as alternative networks not because their practices truly break with conventional systems, but because of the promise of difference that is contained in the projects of the collectives that are implementing them. Seen from this angle, hybridisation and conventionalisation are phenomena related to the actors' 
projects. The divide that the researcher establishes between the "alternative" and "conventional" components of "hybrid spaces" (Ilbery and Maye 2005) does not refer to abstract or essentialised notions but, rather, relates to the projects that the actors put forward. Similarly, assessment of the deterioration or upholding of alternativeness must be done in relation to the projects' asserted ends rather than a general ideal.

In the second part I shall refine the notion of "project". That is necessary because the notion is absent from rural studies and has been defined little in sociological research. Most of the theoretical references on which I shall rely nevertheless come from French sociological research into the constitution of "organised action" (Crozier and Friedberg 1980, Friedberg 1997, Reynaud 1997). These researchers consider both organisations and markets to be collectives created by the establishment of rules. The rules that the actors set themselves are the conditions of their collective action. The sociology of organised action thus shares with the economy of conventions and actor-network theory (ANT), which are better known in rural studies, a concern for the actual conditions under which actions are coordinated. Without written rules, material devices, or quality conventions, agri-food networks could not exist (see, for example, Le Velly and Dufeu 2016, Ponte 2016). Several investigations in the sociology of organised action have, on this basis, also emphasised the importance of the project (Reynaud 1997, Terssac and Lalande 2002, Reynaud 2003, Segrestin 2004, Bréchet et al. 2009). In their view, the ongoing changes in the rules indicate the existence of projects, in the sense of "plans for the future", by means of which the actors assert their ability to imagine new ways of organising the collectives in which they participate. In this same vein, I shall define the project as the reasons and ends that a collective gives itself to turn its action toward a desired future.

This article is mostly theoretical in nature. It is nevertheless rooted in thorough knowledge of fair trade, short food supply chains, and organic agriculture - fields in which I have been working since the early 2000s (Le Velly 2017). I shall refer to the findings of surveys in these fields throughout the article, especially in the third part, in which I shall present two short case studies revolving around fair trade, the first one concerning the diversity of fair trade supply chains set up by the federation Artisans du Monde, which is the main alternative trade organisation in France; and the second one concerning the way the standards committee of Fairtrade International sets fair minimum prices. Through these two case studies we shall see that the project is indeed a central reference, the hub around which rules are set and practices 
are assessed. However, we shall also see how fuzzy a reference it is, one that leaves the door open to negotiation and arbitration.

\section{The projects upon which alternative food networks rest}

I shall start with what I shall call, very simply, "the 'alternative' problem". Why do people speak about "alternative" schemes and systems to refer to initiatives as diverse as fair trade, organic agriculture, and short supply chains? And why does this adjective raise questions in the minds of the very researchers who use it (Section 1.1)? Despite the risk of "dualistic" or "binary" thinking associated with the use of the alternative/conventional pair, I shall reassert how central the challenge to the idea of alternativeness is because of a promise of difference specific to alternative food network projects (in the sense of "plans") (Section 1.2). After that, I shall show that taking account of these projects strengthens the analysis of hybridisation and conventionalisation phenomena (Section 1.3).

\subsection{The "alternative" problem}

Why are schemes as different as short food supply chains, fair trade, organic agriculture, and farm products seen as "alternative" networks? In the late 1990s, the idea behind the first colloquia and the first publications that put this subject on the research agenda was to use this term to identify a set of initiatives that diverged from a globalised, capitalistic, industrial agricultural model that was considered to be dominant. The research stakes at the time were to be able to account for the existence of more marginal, but nevertheless developing, forms of organisation of food networks (Goodman and Watts 1997, Murdoch et al. 2000). This work also had more normative goals. Many of the authors denounced the effects of the conventional system and put forward the need to turn to systems that operated in different ways, even independently from the conventional system. For example, initiatives such as Community Supported Agriculture were described as enabling consumers and farmers to "resist", "to secede from", and to "protect themselves from" the dominant trends in the global food system (Kloppenburg et al. 1996, Hendrickson and Heffernan 2002). The first publications on fair trade show us a very similar line of reasoning. They presented fair trade as an alternative that took shape in "the interstices of globalisation" (Renard 1999) by establishing "re-embedded" relations between producers and consumers (Raynolds 2000). Similarly, articles published during the same period in Europe described short food supply chains, agritourism, on-thefarm processing, organic agriculture, and registered designations of origin as contributing to a 
136 "new rural development paradigm" that would be an answer to the multiple crises plaguing 137 the dominant paradigm of agricultural modernisation (van der Ploeg et al. 2000). They then 138 highlighted the great differences between conventional and alternative agriculture. Whereas 139 the former was deemed to be responsible for farmers' impoverishment, ecological 140 degradation, and health crises, the latter was presented as a source of increased added value 141 on the farm, of environmental conservation, of closer ties to the locality, and of renewed trust 142 between producers and consumers (Marsden et al. 2000).

143 This type of analysis quickly triggered criticism within the very research community that 144 identified with a programme of research into alternative food networks. Its critics pointed to 145 the risk of "binary" or "dualistic" thinking that tended to postulate the existence of a great 146 divide between alternative and conventional food networks (Hinrichs 2003, Goodman 2004, 147 Ilbery and Maye 2005, Morgan et al. 2006, Sonnino and Marsden 2006, Kneafsey et al. 2008). 148 This criticism was based on a number of findings.

149 First, research showed that alternative and conventional food networks were not separate 150 worlds. Typically, researchers found that most of the consumers and producers involved in 151 alternative food networks also participated in conventional schemes, with the consumers 152 doing the majority of their shopping in supermarkets and the farmers producing and/or selling 153 part of their output in conventional networks. Next, the motivations of the participants in 154 alternative food networks were not necessarily very different from those expressed in 155 conventional systems. For example, in the case of short food supply chains, consumers look 156 for tasty products, pay attention to price, and ask for a diverse product line, whilst farmers 157 strive to sell their produce at a good price and do not always want to engage in lengthy 158 discussions with consumers (Hinrichs 2000, Weatherell et al. 2003, Kirwan 2004, Jarosz 159 2008). They also underscored the fact that many alternative food networks mobilised some 160 infrastructure and actors stemming from the conventional system, e.g., industrial 161 slaughterhouses, wholesalers, supermarkets, market price lists, and so on. Far from 162 functioning like a separate space independent from conventional systems, the initiatives under 163 the "alternative" heading presented themselves more as "hybrid spaces" mixing alternative 164 and conventional elements (Ilbery and Maye 2005, Cleveland et al. 2014).

165 A second set of publications, in a continuation of the first wave, stressed the tensions 166 generated by the relationship with the conventional system. The research into the conventionalisation of organic farming that began with Julie Guthman's study of organic farming in California (Guthman 2004), like more recent investigations of the mainstreaming 
of fair trade (Raynolds et al. 2007, Jaffee 2010), emphasised the presence of actors from the conventional system: Capitalistic plantations, agribusiness multinationals, trading companies, and mass distribution brands are currently involved in fair trade and organic agriculture supply chains. This research also showed that alternative food networks were not immune to the industrial production, insecure jobs, price competition, consumer non-information, and other logics attributed to the conventional systems. This inflection of the researchers' views may be explained in part by an inflection of practices, especially in the fair trade sector. However, they also resulted in part from better empirical knowledge and more refined analysis. For example, the literature began showing how omnipresent competitive behaviour was not only amongst fair and non-fair trade products but also amongst the various farmers' organisations involved in fair trade only once in-depth field studies of fair trade farmers' organisations were carried out (Shreck 2002, Taylor et al. 2005).

\subsection{The promise of difference made by the projects underlying alternative food} network

Given such findings, might it not be better to stop using the "alternative/conventional" dichotomy? This risk of "binary" or "dualistic" thinking is what led the authors mentioned in the introduction to defend the idea of abandoning these terms (Maxey 2007, Renting et al. 2012, DiVito Wilson 2013) or to apologise for using them (Kneafsey et al. 2008, Milestad et al. 2010). I plead, on the contrary, in favour of continuing to use this "alternative/conventional" pair, not for reasons of facility, but because it reflects a central characteristic of the initiatives that are associated with alternative food networks.

No longer reasoning in terms of alternative and conventional would amount to losing sight of the very sense of the approaches taken in alternative food networks. Researchers are not alone in thinking of fair trade, CSA, and organic farming as "alternative". For those who promote such initiatives and those that practise them, they are what I call "promises of difference": Promises of other ways of organising production, trade, and/or food consumption and the promise of the associated benefits (Le Velly 2017). When school cafeteria managers decide to buy locally and to reorganise the cafeterias' ways of working accordingly, nothing enables us to say that they do so with the idea of taking part in an alternative food network. However, if they take such action, it is indeed because they hope that such a change will lead to differences for themselves and/or the school children and/or local farmers and/or the environment, etc. The same holds for consumers who decide to take part in a CSA scheme rather than to continue buying their fruit and vegetables at the supermarket, for volunteers and 
professionals who invest in the construction of fair trade supply chains based on specific

203 principles, and so on. Next, researchers, like many other actors, can express reservations as to the likelihood of such promises being realised. However, in so doing, they merely reassert the importance of such promises as references against which the schemes must be evaluated. So, for example, the conventionalisation of organic farming will be assessed as a function of the expected differences between organic and conventional farming.

There are two strands to the promise of difference that alternative food networks extend. The first strand concerns the promise of other ways of organising the production of, trade in, and /or consumption of food compared with those of the dominant conventional systems. The second strand concerns the tangible and intangible benefits of these changes. Gaëlle Balineau and Ivan Dufeu make a clear distinction between these two strands in the case of fair trade. The promise of difference offered by fair trade is not kept if the networks are organised similarly to conventional trade networks. However, it is also not kept if, despite a different organisation, the promised benefits in terms of the producers' development or environmental protection are not achieved (Balineau and Dufeu 2010).

217 This promise of difference is situated in what I call the project. Fair trade, short supply chains, 218 and so on, benefit from being seen as alternative food networks. This is not because their practices truly break with conventional systems, but due to the promise of difference that their projects for the future offer. Oppositions such as fair trade v. conventional trade, organic farming v. conventional farming, slow food v. fast food, short supply chains v. long supply chains, artisanal production v. industrial production, chemistry v. nature, and so on should be taken serious. These oppositions must not be considered to be mere caricature-like short cuts. As elements of such projects they are vectors of change, and the turn-of-the-21st century publications presented above must consequently be reread from this perspective. Highlighting a "new rural development paradigm" (van der Ploeg et al. 2000) does not simply boil down to describing and analysing what exists. It also means moving towards desirable changes.

The second part of this article will describe the project as the reasons and ends that a collective gives itself to orient its action towards a desired future. However, before delving into this definition, I should like to stress how the collectives' projects are presented and observable in alternative food networks. Many alternative network initiatives give rise to relatively general documents that express the grand purposes and broad lines of their action (examples include the International Federation of Organic Agriculture Movement's (IFOAM) 
235 France, etc.). The promotional materials that the actors use to present their approaches (press

236 files, Internet sites, advertising, etc.) are also good ways to observe their projects. The 237 promise of being different from "conventional trade" is asserted and omnipresent in the fair 238 trade world and incarnated in a series of oppositions. Boosting the development of the "small 239 farmers" who are the victims of the "big multinationals" of conventional trade; paying a fair 240 price that allows for the farmer's situation rather than a market price set by the blind forces of 241 supply and demand; establishing ties that are as direct as possible to prevent a series of 242 middlemen getting rich at the farmers' expense; engaging in partnerships aimed at 243 development rather than choosing suppliers based on a purely profit-seeking rationale; and 244 acting as a "consum'actor" rather than passively taking in the messages of a consumer society 245 are all promises of difference at the heart of the fair trade project.

246 One might retort that such messages are merely examples of skilful, more-or-less cynically 247 distilled communication that should not be given undue importance. My lengthy experience 248 with fair trade initiatives, but also with short supply chains and organic farming, prompts me 249 to contest this argument. The highlighted oppositions must not be considered to be discourse 250 aimed simply at putting the initiatives concerned in a better light. They are components of the collective projects underlying alternative food networks. These promises of difference are not empty promises, as attested by the fact that the actors themselves refer to them constantly in assessing their actions. For example, even though the principles laid down in the AMAP

254 Charter (AMAPs being the French equivalent of North American community-supported agriculture (CSA) groups) are implemented in very wide variety of ways (Mundler 2007), the AMAPs' participants all refer to them to judge their practices. For example, they may rue the fact that their market gardener's cropping system is not very agroecological, but will accept it in light of another principle, that of helping a farmer to get through an economic rough patch and survive.

\subsection{Hybridisation and conventionalisation are relative to the projects}

261 Taking account of AFNs' projects and promises of difference makes it possible to back up the analysis of hybridisation and conventionalisation. Since we consider that these two phenomena relate to the alternative food network promoters' projects, the "alternative" and "conventional" categories to which they refer are no longer abstract or essentialised notions, and the criticism made on this point by researchers wishing to abandon this vocabulary is not valid anymore (Maxey 2007, Renting et al. 2012, DiVito Wilson 2013). 
Speaking of "hybrid spaces" (Ilbery and Maye 2005) to describe alternative food networks speaks volumes, but is not sufficient for their analysis. So, once it has been ascertained that alternative food networks mix actors and rules that are in part "conventional" and in part "alternative", it is also necessary to justify how the researcher establishes the boundary between the two sets. In working on various initiatives to relocalise the food supplies of collective catering (sourcing them locally again), I suggested tackling this question from the standpoint of the organisational innovation processes that were activated (Le Velly 2017). I call the rules aimed specifically at implementing the project's promise of difference "alternative rules". These alternative rules differ from the pre-existing rules, some of which are replaced by the new rules and others of which remain in the new organisation. So, in the case of collective catering, implementing a project to source food supplies locally entails drawing up specific alternative rules. It will be necessary, for example, to forge new trade relations with farmers or distributors able to provide local produce, but also to change the quality of the produce ordered, menus and recipes, organisation of work in the kitchen, service given to the children in the school cafeterias, and so on (Le Velly 2017; see also Morgan and Sonnino 2008). Some existing conventional rules will be dropped as a result, but others will remain in effect (e.g., public procurement rules, hygiene standards, industrial equipment already on site, price levels set by prior negotiations with former suppliers, etc.) (Le Velly 2017; see also Klein 2015). Such an analysis backs up the idea of the hybridisation of alternative and conventional practices, but also strengthens the analysis by making the way the researcher establishes the divide between alternative and conventional rules more explicit (in the same vein, see, for a complex system of subscriptions to fish boxes: Le Velly and Dufeu 2016).

This reasoning applies as well to conventionalisation. Conventionalisation must also be seen in relation to the project. Several researchers into the conventionalisation of organic agriculture do indeed refer to the principles of IFOAM - the main international organic agriculture movement - to determine on which points and to what extent conventionalisation takes place (Padel et al. 2009, Darnhofer et al. 2010). This type of analysis can already raise the following question: Do these principles make sense to all the actors in the organic sector? It is already more convincing to refer, as Guthman did, to a list of principles set by the organic farmers in the surveyed region (Guthman 2004). Still, referring explicitly to IFOAM's principles already makes things more explicit than many of the research projects that assess conventionalisation according to criteria that do not refer to an explicit project. If the project 
as a function of which conventionalisation is assessed is not made explicit, analysis tends to turn the alternative and conventional references used to assess practices into essentials. Under such conditions, it is possible to wonder, along with Angela Tregaer, whether the research that is most critical of conventionalisation refers more to the researchers' projects than to those of the actors concerned (Tregear 2011).

\section{Definition and properties of the notion of project}

The arguments broached in the first part of this article plead in favour of taking account of the project in analysing alternative food networks. To continue in this direction, it is now necessary to specify the properties that I associate with this notion. For this, I shall rely on the work of French sociologists involved in a more general questioning of "organised action". I shall start by giving a definition of the project (Section 2.1.), and then clarify the respective contributions of projects and rules in constituting collective action as I see them (Section 2.2.).

\subsection{Definition of "project"}

In everyday French, the word "projet" echoes a wide range of different types of reality that are also expressed by terms such as plan, programme, intention, strategy, idea, etc. Most important, the notion of "project" as a "plan for the future" is not a well-established sociological concept. For example, it is not found in any of the major dictionaries of sociology published by Oxford, Cambridge, Routledge, Blackwell, and Sage. Introducing the notion of "project", with its implications of creativity, vision, and purposiveness, into the analysis of alternative food networks thus requires starting by specifying the properties of this notion.

In French sociology, a substantial effort was made to do just that in the founding texts of Jean-Pierre Boutinet and Jean-Daniel Reynaud (Boutinet 1990, Reynaud 1997) and the more recent publications of Jean-Pierre Bréchet and his co-authors (Bréchet et al. 2009, Bréchet and Prouteau 2010). The latter defined the project as "a fuzzy operative expectation of a desired future" (Bréchet et al. 2009, p. 41). The project is an operative by means of which individuals imagine a future that they deem desirable and conceive of its broad characteristics. The project that is so defined can be individual or collective. It can be a personal project or a corporate plan. However, in the second case, one must add issues of coordination. To be able to act together, people must have common landmarks that give meaning and direction to the creation and evolution of the collective. 
331 The definition used herein belongs to this vein of work. I see the project as the reasons and 332 ends that a collective gives itself to orient its action towards a desired future. Let us consider 333 this definition in three steps.

334 First, this definition puts the notion of project in the realm of the general questioning about 335 the inception of collective action, for the "collective" in the definition can be a business, 336 trades union, NGO, or any other organisation. However, it is interesting to go beyond this 337 strictly "organisational" vision to include observable phenomena of more "market-related" 338 collectives, such as supply chains and market places, in its scope. Such a broadening of the 339 notion does not lack theoretical foundations. For the sociology of organised action, both 340 organisations and markets are plagued by common coordination problems: It is necessary to 341 distribute labour, set wages, determine desirable and unacceptable behaviours, agree on the 342 principles of evaluating people and goods, etc., in both cases (Friedberg 1997). The 343 perspective adopted is thus close to that of pragmatist sociology, a current developed in the 344 economy of conventions in particular. To deal with the many coordination issues linked to 345 carrying out collective action, be it in an organisation or on a market, the collective must be 346 organised on the basis of shared landmarks (Thévenot 1984). Stated in the terms of actor347 network theory (ANT), organisations and markets alike share the property of being "hybrid 348 collectives", "agencements" in which human and non-human actors (rules, laws, devices, etc.) 349 act in concert (Callon and Law 1995, Çalişkan and Callon 2010). Reasoning in these terms is 350 particularly relevant for working on alternative food networks. A CSA network, fair trade 351 network, relocalised supply chains, slow food convivium, and so on are all initiatives that can 352 be considered good examples of "collectives" informed by their actors' projects. ${ }^{\text {i }}$

353 Second, this definition of the project leads us to look closely at the "reasons and ends", the 354 simultaneously interpretive, cognitive, and normative frameworks underlying the inception of 355 collective action. The fair trade project as expressed repeatedly in the various "charters" and 356 "statements of principles" and promotional materials alike illustrates this point. It includes 357 denouncing the malfunctions of "conventional trade" (low prices paid to farmers, poor 358 working and living conditions, etc.), identifying the causes of this situation (greediness of 359 trade intermediaries, speculation on agricultural commodities, etc.), asserting the aims of fair 360 trade (making farmers autonomous, establishing a "fair price", etc.), and identifying some 361 major principles (guaranteeing a minimum price, creating long-lasting partnerships, etc.). This 362 whole determines the meaning and direction of work. The project is the engine: The discourse 363 that it generates justifies doing something, acting in favour of fair trade. Next, it is a reference 
364 that orients action, a guide for establishing "alternative rules" that set the promise of 365 difference in motion. Finally, it is a framework for assessment. As we shall see in the third 366 part, the performance, be it good or bad, of fair trade networks is judged according to the ends 367 that are stated in the project.

368 Third, writing that the project is turned toward conceiving of a more desirable future is aimed 369 at thinking of the project as being relevant to a specific dimension of agency or mode of 370 action. "What is agency?" (Emirbayer and Mische 1998; see Bréchet and Prouteau 2010) is an 371 article that must be read for its invaluable contributions in this regard. In it, Mustafa 372 Emirbayer and Ann Mische identify three major dimensions of agency. They make a first distinction between the "iterative" and "practical evaluative" dimensions of agency, i.e., routine versus reflective action. Then, referring in particular to the work of Hans Joas (Joas 1996), they underline human beings' creativity, their abilities to imagine new states of the world and to launch their construction. They call this third dimension of agency "projective". Each mode of action belongs to a different time frame: Whilst iterative agency takes the form of a reiteration of past actions and practical evaluative agency involves assessing current actions, projective agency marks the ability to imagine and to conceive broadly of other actions for the future. Recognising this third dimension of agency thus leads one to think of the collective's ability to initiate its own transformation through its projects for the future. According to Mische, the project is like a magic rope: Once the actors have thrown it in front of themselves, their project becomes the ladder of their own ascension (Mische 2009). Such a notion of the project can contribute considerably to the study of "food utopias" such as researchers in rural sociology have recently embarked upon (Stock et al. 2015). Just as in these investigations, referring to the project allows one to study how the criticism levelled at conventional systems fuels experiments and processes of change. In addition, by emphasising the actors' creativity and possible transformations of food systems, such reference to the project shares with this vein of research a scientific stance that is deliberately a vector of hope (Carolan 2013, Forney 2016, Kristensen and Kjeldsen 2016; see also Gibson-Graham 2008).

\subsection{Projects and rules}

392 After this first effort to define the notion of a project, I shall continue to rely on the sociology 393 of organised action to show how rules and projects are connected. Such clarification is 394 necessary in order not to overestimate the place of the project in the scheme of things. 
395 First it is necessary to point out that the creation of a collective involves both projects and 396 rules. This point has been stressed most particularly in the sociology of organised action by 397 Reynaud and sociologists following in his wake (Reynaud 1997, Reynaud 2003, Terssac and 398 Lalande 2002, Segrestin 2004, Bréchet et al. 2009). Denis Segrestin, for example, stressed the 399 importance of the "founding utopias", of the "projects set by their actors" that were 400 instrumental in the development of numerous organisational innovations in France in the 401 1980s (innovations regarding quality management, outsourcing, partnerships, and so on). In 402 his opinion, all these developments have to be understood as occurring at the intersection of 403 changes in rules and changes in projects. For example, skills management was promoted and 404 the rules governing salaried employment were revised in the name of a new way of 405 considering the value of labour and the career. Such an approach prevents overestimating the centrality of rules and of projects alike: Without a project, rules have no meaning, but without rules, projects cannot be implemented. Projects and rules make interwoven contributions to 408 the creation and development of collectives.

409 Next it is necessary to establish clearly that the projects do not determine the rules 410 mechanically and the rules are not the direct application of the project. To underscore this 411 point, the researchers defending the notion of the project usually point out that projects are 412 "blurry", "vague" references. Reynaud explains that the project must be understood not as 413 "well-determined objectives and a plan to achieve them" but rather as "a social adventure 414 with a horizon that remains vague" (Reynaud 2003, p. 112). Let us remember as well that 415 Bréchet and his colleagues define the project as "a fuzzy operative expectation of a desired 416 future" (Bréchet et al. 2009, p. 41). Similarly, Emirbayer and Mische explain that the project's 417 sights are set on "an often vague and indeterminate future horizon" (Emirbayer and Mische 418 1998, p. 989). Finally, whilst Segrestin sees himself as echoing the cultural frames that inspire 419 organisational innovations, he is far from making them the only determinants of change. On 420 the subject of management software packages, for example, he writes, "the tool is saturated 421 with more or less antinomic utopias. It is thus in a weak state and forced to let its users choose 422 between contrary causes whenever they come up" (Segrestin 2004, p. 316).

423 I concur with this position that projects are fuzzy references. Insisting on this is by no means 424 an attempt to criticise them for a lack of robustness. That would be a classical type of 425 reasoning in the sociology of organised action identical to the reasoning used with regard to 426 the ambiguousness of the rules that apply (Crozier and Friedberg 1980): In the same way as 427 the rules do not determine the action completely, but always leave some room for manoeuvre, 
the project does not determine the rules completely. Consequently, setting the project in motion can only be the result of arbitration and negotiation.

\section{From the project to the rules: Two brief fair trade case studies}

To illustrate these theoretical developments, let us refer to two surveys carried out on two fair trade organisations, namely, the federation Artisans du Monde and Fairtrade International. Like other alternative food networks, fair trade has been described as a hybrid space, mixing alternative and conventional devices (Whatemore and Thorne 1997). Research also highlighted some conventionalisation trends and observed different levels of alternativeness amongst various fair trade organisations (Raynolds et al. 2007, Jaffee 2010). It is useful to identify the fair trade project clearly as the reference against which such judgements are made. This reference is present, more or less explicitly, in researchers' work, but it is also present in fair trade promoters' minds. In this third part, I shall show that the fair trade project is an important landmark for the establishment of fair trade rules. But, I shall also show that the project's fuzziness generates arbitration and negotiation. With the Artisans du Monde case we shall see how the rules that govern fair trade networks are the result of arbitrating amongst the various goals of the fair trade project (Section 3.1). The Fairtrade International case also heads in this direction, with a focus on one central rule, namely, setting a fair minimum price (Section 3.2.).

\subsection{Artisans du Monde: Rules that result from arbitrating amongst the goals of the} project

The federation Artisans du Monde carried out a survey in the first half of the 2000s to assess the impact of its action on the producers' organisations with which it had long-standing fair trade relations. ${ }^{\text {ii }}$ A major result of this study was to highlight how diverse the supply chains established with these farmers/producers were. The federation's activists were informed of this result at national or regional general meetings, training sessions, new product range presentation days, and so on, and I attended quite a few of those events at the time. The federation's leaders emphasised the findings that might appear to be upsetting. It was thus interesting to see how the attending activists received these findings. These situations gave insights into how the activists referred to the fair trade project to assess the various supply chains that had been set up. Their feeling was that it was impossible to comply with all the 
principles and aims of fair trade simultaneously. The rules that were established were the results of arbitrating amongst and ranking the various components of the project.

The ways that the various fair trade supply chains did or did not make it possible to work with highly marginalised producers were the crux of the discussions. Asserting the ability to provide outlets for organisations of "marginalised producers" that are unable to develop in conventional trade supply chains because of their members' disabilities or discriminations of all sorts is an important objective of the fair trade project. Yet, for all that, in practice this principle frequently comes up against two other principles of fair trade, to wit, (1) achieving autonomy for the producers through the market and (2) providing quality products. The project thus affirms the objectives of reinforcing the producers' organisations so that they do not depend on fair trade purchases and ensuring an egalitarian North/South partnership ("Trade, not charity"). When the findings of the study of their work's impact were shared with the base, the latter observed with regret that while the long-standing relations that had been established with highly marginalised groups of farmers and craftsmen had indeed improved these groups' daily lot, they had not generated any development processes. In particular, the marginalised producers had not become autonomous players, given the poor quality of their products and small sales volumes. On the other hand, the attending activists learnt, with just as much uneasiness, that the commercially most dynamic supply chains, those from which the network bought the largest amounts, involved organisations that had numerous outlets, including outside the realm of fair trade. In such cases, was it possible to continue speaking of "marginalised producers"? So, even though certain activists were personally more comfortable with one or the other of these two types of supply chain, none of them seemed completely happy with these findings. On the contrary, everyone saw quite clearly that the fair trade project was not fully achieved in either of the two cases.

If truth be told, certain supply chains seemed to have solved this problem. However, they managed to do so only by moving away from another aim of fair trade, that of establishing direct, personalised relations with the producers' organisations. An important conclusion of the study of Artisan du Monde's impact was that it was possible to work with marginalised producers whilst engaging autonomisation processes by means of the market. However, that entailed the intervention of development organisations and central export offices to support the producers' efforts to organise and to raise the quality of their produce or goods. This type of supply chain thus led to the establishment of relations involving a large number of intermediaries between the activists manning the points of sale and the "small 
491 farmers/craftsmen", to the point of making the latter invisible behind the development 492 organisations that represented them (Ballet and Carimentrand 2010). What is more, it could 493 also be marked by a strong tendency to adjust product design to meet Western consumers' 494 tastes, even to the point of going against one last fair trade principle that is frequently asserted 495 with regard to handicrafts, namely, respect for local know-how and cultural authenticity 496 (Grimes and Milgram 2000).

497 The fair trade project is "fuzzy", "vague", and "ambiguous" (for comparable findings for a 498 domestic fair trade project, see Feyereisen et al. 2017, and for food sovereignty, see Wald 499 2015). Implementing it through specific rules entails arbitrating and establishing a hierarchy 500 of its various components. In no way does showing this mean denying the importance of the project. All the arbitration that is done continues to be guided by the project. The mixed feelings of Artisans du Monde's activists in respect of the impact study findings attest to that.

503 Even if the project is not a perfect template for their collective action, it nonetheless is indeed a landmark, a source of intelligibility and structural guidance for it.

\subsection{Fairtrade International: setting a fair minimum price}

The fuzziness of the fair trade project is also important to determine in which interpretive and normative framework a central rule is established, that of setting the minimum prices at which Fairtrade International buys from producers. Whilst such minimum prices are not set in all fair trade supply chains, they are for most of the agricultural commodities certified by Fairtrade International, which is the principal global fair trade standards body. ${ }^{\text {iii }}$

Fairtrade International's minimum price standards are updated periodically according to a specific procedure that goes from an official request by a stakeholder to the decision taken by the Standards Committee. Between these two points, Fairtrade International organises a public consultation, commissions studies, and drafts proposals for modifications. The Standards Committee then arbitrates amongst the various options. A Fairtrade International document sums up the principles that are supposed to guide the setting of these minimum prices as shown below. This text is remarkable in that it seems to say everything and its contrary!

The Fairtrade minimum price (FMP) is based on the principle of covering average costs of sustainable production of the products, while enabling the average producer to produce in an economic and financial [sic] sustainable way without systematic economic losses. This requires not only covering the average costs of sustainable production but also considering market acceptance to ensure that the FMP does not 
compromise the ability to sell the product. The FMP is thus designed as a floor price which covers the average costs of sustainable production (which can be calculated by use of the sheet in Annex 1) of producers and at the same time allows these producers to have access to their product markets. This can imply that the FMP is fixed below the average costs of sustainable production. (Fairtrade International, Standard operating procedure development of Fairtrade minimum prices and premiums, January 2015)

In practice, the setting of a minimum price can indeed refer to one ("covering costs of sustainable production") or the other ("considering market acceptance") of these two rationales. In 2007, Juliane Reinecke spent six months observing the way the Standards Committee worked (Reinecke 2010). At the time of her investigation, this committee was composed of two representatives of producers organisations, two representatives of the importers, and two representatives of the network's "national initiatives". The committee had to respond at the time to the request of the Latin American Confederation of Certified Producers $^{\text {iv }}$ to increase the minimum price of coffee. To back up their request, the South American coffee farmers produced detailed data on their rising costs and falling purchasing power. However, Reinecke explains, some of the Standards Committee members contested the relevance and objectiveness of the computations. It was also argued that a high price policy could help to keep economically inefficient producers organisations in the system.

541 Finally, the risk of losing outlets was also put forward. In other words, imposing a high minimum price was seen as possibly generating sales prices that were too high for consumers but also carrying the risk of prompting some market operators to leave the Fairtrade network. These arguments prevailed, and the committee finally decided to raise the minimum price, but by a smaller amount than requested by the Latin American producers' confederation (Bacon 2010).

Such negotiations within the bodies of Fairtrade International can obviously be interpreted as the expression of conflicts and balances of power amongst the various actors in the system (Renard 2005, Raynolds et al. 2007). Yet, for all that, these conflicts gain from being examined in detail in light of the ambiguousness of the fair trade project and the bargaining space that it allows. Increasing a minimum price to allow for the rising costs of sustainable production and not increasing it to allow for market restraints are two contrary positions that refer to the same project. Whilst the search for high prices is justified by the desire to support

554 the efforts made by more ecological production systems and to improve the producers' living conditions, the possibility of setting prices below these same costs cannot be ruled out if the 
end result is to generate sales and trigger more extensive development processes. The

557 fuzziness of the fair trade project is precisely what enables the various parties to refer to one or the other of its dimensions to justify and develop its strategy.

\section{Conclusions}

560 This article argues in favour of introducing the notion of project in the analysis of alternative

561 food networks. I believe that this notion fills a gap in existing research. It provides a solid 562 foundation for the very use of the term "alternative", to wit: Fair trade, short supply chains, 563 organic agriculture, local produce, etc., deserve to be studied as "alternative" systems because 564 these collectives are motivated by the promise of difference that their projects harbour. 565 Working on the alternative/conventional hybridisations that make up alternative food 566 networks then amounts to identifying the rules that are specifically established to set this 567 promise of difference in motion, i.e., "alternative rules", and to analyse how these alternative 568 rules connect with the pre-existing conventional rules. Similarly, and still from this perspective, the degree of conventionalisation of an alternative network will be measured by the yardstick of the alternative ends that the project asserts rather than by referring to a general ideal of alternativeness.

572 After putting forward these arguments, I clarified the properties of the notion of project and 573 proposed a definition that restores the importance of the cultural and cognitive frameworks 574 that support the creation of collective action and recognises the agents' creative ability to 575 imagine and to construct new states of the world. I also stressed the way the project and rules participate jointly in constituting the collective. I explained that the project must not be seen as a clear determinant of the rules but rather as a fuzzy landmark, a "vague horizon". Setting the rules must not be mistaken for implementing the project directly, which results instead from the interpretation of and negotiations that take place around the project (.

580 Other contributions will be necessary to further our understanding of the role of the project in 581 alternative food networks. In particular, field surveys are required to grasp better how their 582 projects take shape. Several sub-questions on this point can be identified. Recognising human 583 beings' ability to act projectively, as Emirbayer and Mische (1998) urge us to do, must not lead to losing sight of the actors' unequal abilities to envision new states of the world. The ability to contest existing rules in order to draw up new collectives is a sociological property 586 that must be understood better. Which networks and knowledge are necessary to imagine new states of the world (Goodman et al. 2012)? How do the multiple socio-technical lock-ins that 
constrain action prevent the emergence of projects that promise alternatives (Lamine et al. 2012)? Finally, how are the projects affirmed in action, through experiments and learning processes in which projects and rules are constantly being redefined?

It is also necessary to improve our understanding of how the various scales of projects are embedded in each other. Concretely, fair trade and organic agriculture alike are subtended by a general project that is expressed in "charters" or "principles" by the collectives of organisations that operate on the international (World Fair Trade Organisations, International Federation of Organic Agriculture Movements) or national (French Fair Trade Platform, National Federation of Organic Farming in the case of France) scale. However, whilst they identify with these general projects, organisations also assert their own fair trade or organic agriculture projects. This is, for instance, the case of the French fair trade federation Fédération Artisans du Monde and Norabio, an organic agriculture cooperative in the north of France. What is interesting in these two cases is that the overall project remains a reference that exerts a very strong attractive force, to the point that organisations with opposing strategies regarding, for example, selling through supermarkets continue to refer to the same ends and general principles. The mobilising force of the project does not require the individuals who identify with it to adopt it totally. Once again, thinking of the project as being fuzzy, and thus having the ability to unite actors whose aims are not identical, avoids the pitfall of an overly culturalist perspective.

Finally, it is also important to grasp how a general project can produce an economic sector such as fair trade or organic agriculture when the project itself is a vague or fuzzy reference. On the one hand, the fuzziness of fair trade and organic agriculture is a strength in that it allows the construction of economic sectors that include a great variety of actors and positions (Kjeldsen and Ingemann 2009, Rosin and Campbell 2009). But, on the other hand, it is also a weakness, in that the different interpretations of the project can lead to such divergent rules as to jeopardise the unity of the sector. By no means does including the project in the analysis overestimate its power in social processes. Its power as much as its weakness is precisely what must be explored.

\section{Acknowledgements}

I gratefully acknowledge the help provided by Stéphanie Barral, Jean-Pierre Bréchet, Ivan Dufeu, Olivier De Schutter, Sophie Dubuisson-Quellier, Frédéric Goulet, Moya Kneafsey, Diane Rodet, Bettina Bock and Sociologia Ruralis's reviewers for comments on earlier 
620

621

622

623

624

625

626

627

628

629

630

631

632

633

634

635

636

637

638

639

640

641

642

643

644

645

646 (Chicago: Chicago University Press)

647 Darnhofer, I., T. Lindenthal, R. Bartel-Kratochvil and W. Zollitsch (2010) 648 Conventionalisation of organic farming practices: From structural criteria towards an

versions of this paper. I also thank Gabrielle Leyden for the quality of her translation. This research has been funded by the French National Research Agency (grant ANR-15-CE210006 'Institutionnalisation des agroécologies').

\section{References}

Bacon, C.M. (2010) Who decides what is fair in fair trade? The agri-environmental governance of standards, access, and price. The Journal of Peasant Studies 37 (1) pp. 111-147

Balineau, G. and I. Dufeu (2010) Are fair trade goods credence goods? A new proposal, with French illustrations. Journal of Business Ethics 92 (2) pp. 331-345

Ballet, J. and A. Carimentrand (2010) Fair trade and the depersonalization of ethics. Journal of Business Ethics 92 (2) pp. 317-330

Boutinet, J.-P. (1990) Anthropologie du projet (Paris: PUF)

Bréchet, J.-P. and L. Prouteau (2010) A la recherche de l'entrepreneur. Au-delà du modèle du choix rationnel : Une figure de l'agir projectif. Revue française de socio-Economie (6) pp. 109-130

Bréchet, J.-P., N. Schieb-Bienfait and A. Desreumaux (2009) Les figures de l'entrepreneur dans une théorie de l'action fondée sur le projet. Revue de l'entrepreneuriat 8 (1) pp. 37-53

Çalişkan, K. and M. Callon (2010) Economization, part 2: A research programme for the study of markets. Economy and Society 39 (1) pp. 1-32

Callon, M. and J. Law (1995) Agency and the hybrid «collectif». The South Atlantic quarterly 94 (2) pp. 481-507

Carolan, M.S. (2013) The wild side of agro-food studies: On co-experimentation, politics, change, and hope. Sociologia Ruralis 53 (4) pp. 413-431

Cleveland, D.A., N.M. Müller, A.C. Tranovich, D.N. Mazaroli and K. Hinson (2014) Local food hubs for alternative food systems: A case study from Santa Barbara county, California. Journal of rural studies 35 (1) pp. 26-36

64 Crozier, M. and E. Friedberg (1980) Actors and systems: The politics of collective action 
649 assessment based on organic principles. A review. Agronomy for Sustainable Development $65030(1)$ pp. $67-81$

651 DiVito Wilson, A. (2013) Beyond alternative: Exploring the potential for autonomous food 652 spaces. Antipode 45 (3) pp. 719-737

653 Emirbayer, M. and A. Mische (1998) What is agency? American journal of sociology 103 (4) 654 pp. $962-1023$

655 Feyereisen, M., P.M. Stassart and F. Mélard (2017) Fair trade milk initiative in Belgium: 656 Bricolage as an empowering strategy for change. Sociologia Ruralis 57 (3) pp. 297-315

657 Forney, J. (2016) Enacting Swiss cheese: About the multiple ontologies of local food. Pp. 6765881 in R. Leheron, H. Campbell, N. Lewis and M. Carolan eds., Biological economies: 659 Experimentation and the politics of agri-food frontiers (London and New York: Routledge)

660 Friedberg, E. (1997) Local orders: Dynamics of organized action (Greenwich: Jai Press)

661 Gibson-Graham, J.K. (2008) Diverse economies: Performative practices for 'other worlds'. 662 Progress in Human Geography 32 (5) pp. 613-632

663 Goodman, D. (2004) Rural Europe redux? Reflections on alternative agro-food networks and 664 paradigm change. Sociologia Ruralis 44 (1) pp. 3-16

665 Goodman, D., M. DuPuis and M. Goodman (2012) Alternative food networks. Knowledge, 666 practice and politics (London: Routledge)

667 Goodman, D. and M.J. Watts (eds.) (1997) Globalising food: Agrarian questions and global 668 restructuring (London, Routledge)

669 Grimes, K.M. and B.L. Milgram (eds.) (2000) Artisans and cooperatives: Developing 670 alternative trade for the global economy (Tucson, University of Arizona Press)

671 Guthman, J. (2004) Agrarian dreams: The paradox of organic farming in California 672 (Berkeley: University of California Press)

673 Hendrickson, M.K. and W.D. Heffernan (2002) Opening spaces through relocalization: 674 Locating potential resistance in the weaknesses of the global food system. Sociologia Ruralis $67542(4)$ pp. 347-369

676 Hinrichs, C.C. (2000) Embeddedness and local food systems: Notes on two types of direct 677 agricultural market. Journal of rural studies 16 (3) pp. 295-303 
678 Hinrichs, C.C. (2003) The practice and politics of food system localization. Journal of rural 679 studies 19 (1) pp. 33-45

680 Ilbery, B. and D. Maye (2005) Alternative (shorter) food supply chains and specialist 681 livestock products in the Scottish - English borders. Environment and planning A 37 (5) pp. $682 \quad 823-844$

683 Jaffee, D. (2010) Fair trade standards, corporate participation, and social movement responses 684 in the United States. Journal of Business Ethics 92 (2) pp. 267-285

685 Jarosz, L. (2008) The city in the country: Growing alternative food networks in metropolitan 686 areas. Journal of rural studies 24 (3) pp. 231-244

687 Joas, H. (1996) The creativity of action (Cambridge: Polity press)

688 Kirwan, J. (2004) Alternative strategies in the UK agro-food system: Interrogating the alterity 689 of farmers' markets. Sociologia Ruralis 44 (4) pp. 395-415

690 Kjeldsen, C. and J.H. Ingemann (2009) From the social to the economic and beyond? A 691 relational approach to the historical development of Danish organic food networks. Sociologia 692 Ruralis 49 (2) pp. 151-171

693 Klein, K. (2015) Values-based food procurement in hospitals: The role of health care group 694 purchasing organizations. Agriculture and human values 32 (4) pp. 635-648

695 Kloppenburg, J., Jr., J. Hendrickson and G.W. Stevenson (1996) Coming in to the foodshed. 696 Agriculture and human values 13 (3) pp. 33-42

697 Kneafsey, M., L. Holloway, L. Venn, E. Dowler, R. Cox and H. Tuomainen (2008) 698 Reconnecting consumers, producers and food: Exploring alternatives (Oxford: Berg 699 Publishers)

700 Kristensen, D.K. and C. Kjeldsen (2016) Imagining and doing agro-food futures otherwise: 701 Exploring the pig city experiment in the foodscape of Denmark. Journal of rural studies $43 \mathrm{pp}$. $702 \quad 40-48$

703 Lamine, C., H. Renting, A. Rossi, J.S.C. Wiskerke and G. Brunori (2012) Agri-food systems 704 and territorial development: Innovations, new dynamics and changing governance 705 mechanisms. Pp. 229-256 in I. Darnhofer, D. Gibbon and B. Dedieu eds., Farming systems 706 research into the 21st century: The new dynamic (Springer Netherlands) 
707 Latour, B. (2005) Reassembling the social: An introduction to actor-network-theory (Oxford:

708 Oxford University Press)

709 Le Velly, R., 2017. Sociologie des systèmes alimentaires alternatifs. Une promesse de 710 différence. Presses des Mines, Paris.

711 Le Velly, R. and I. Dufeu (2016) Alternative food networks as "market agencements":

712 Exploring their multiple hybridities. Journal of rural studies 43 pp. 173-182

713 Marsden, T., J. Banks and G. Bristow (2000) Food supply chain approaches: Exploring their 714 role in rural development. Sociologia Ruralis 40 (4) pp. 424-438

715 Maxey, L. (2007) From 'alternative' to 'sustainable' food. Pp. 55-75 in D. Maye, L. Holloway 716 and M. Kneafsey eds., Alternative food geographies. Representation and practice (Bingley: 717 Emerald)

718 Milestad, R., R. Bartel-Kratochvil, H. Leitner and P. Axmann (2010) Being close: The quality 719 of social relationships in a local organic cereal and bread network in lower Austria. Journal of 720 rural studies 26 (3) pp. 228-240

721 Mische, A. (2009) Projects and possibilities: Researching futures in action. Sociological 722 Forum 24 (3) pp. 694-704

723 Morgan, K., T. Marsden and J. Murdoch (2006) Worlds of food: Place, power, and 724 provenance in the food chain (Oxford: Oxford University Press)

725 Morgan, K. and R. Sonnino (2008) The school food revolution: Public food and the challenge 726 of sustainable development (London: Earthscan)

727 Mundler, P. (2007) Les associations pour le maintien de l'agriculture paysanne (amap) en 728 Rhône-Alpes, entre marché et solidarité. Ruralia (20) online

729 Murdoch, J., T. Marsden and J. Banks (2000) Quality, nature, and embeddedness: Some 730 theoretical considerations in the context of the food sector. Economic Geography 76 (2) pp. $731 \quad 107-125$

732 Padel, S., H. Röcklinsberg and O. Schmid (2009) The implementation of organic principles 733 and values in the European regulation for organic food. Food Policy 34 (3) pp. 245-251

734 Ponte, S. (2016) Convention theory in the anglophone agro-food literature: Past, present and 735 future. Journal of rural studies 44 pp. 12-23 
736 Raynolds, L.T. (2000) Re-embedding global agriculture: The international organic and fair 737 trade movements. Agriculture and human values 17 (3) pp. 297-309

738 Raynolds, L.T., D.L. Murray and J. Wilkinson (eds.) (2007) Fair trade. The challenges of transforming globalization (New York, Routledge)

740 Reinecke, J. (2010) Beyond a subjective theory of value and towards a 'fair price': An 741 organizational perspective on Fairtrade minimum price setting. Organization 17 (5) pp. 563 $742 \quad 581$

743 Renard, M.-C. (1999) The interstices of globalization: The example of fair coffee. Sociologia 744 Ruralis 39 (4) pp. 484-500

745 Renard, M.-C. (2005) Quality certification, regulation and power in fair trade. Journal of rural 746 studies $21(4)$ pp. 419-431

747 Renting, H., M. Schermer and A. Rossi (2012) Building food democracy: Exploring civic 748 food networks and newly emerging forms of food citizenship. International journal of 749 sociology of agriculture and food 19 (3) pp. 289-307

750 Reynaud, J.-D. (1997) Les règles du jeu. L'action collective et la régulation sociale (third 751 edition) (Paris: Armand Colin)

752 Reynaud, J.-D. (2003) Régulation de contrôle, régulation autonome et régulation conjointe. 753 Pp. 3-36 in G. Terssac de ed., La théorie de la régulation sociale de Jean-Daniel Reynaud. 754 Débats et prolongements (Paris: La découverte)

755 Rosin, C. and H. Campbell (2009) Beyond bifurcation: Examining the conventions of organic 756 agriculture in New Zealand. Journal of rural studies 25 (1) pp. 35-47

757 Segrestin, D. (2004) Les chantiers du manager (Paris: Armand Colin)

758 Shreck, A. (2002) Just bananas? Fair trade banana production in the Dominican Republic. 759 International journal of sociology of agriculture and food 10 (2) pp. 13-23

760 Sonnino, R. and T. Marsden (2006) Beyond the divide: Rethinking relationships between 761 alternative and conventional food networks in Europe. Journal of Economic Geography 6 (2) 762 pp. 181-199

763 Stock, P., V., M. Carolan and C. Rosin (eds.) (2015) Food utopias. Reimagining citizenship, 764 ethics and community (London, Routledge) 
765 Taylor, P.L., D.L. Murray and L.T. Raynolds (2005) Keeping trade fair: Governance 766 challenges in the fair trade coffee initiative. Sustainable Development 13 (3) pp. 199-208

767 Terssac, G.d. and K. Lalande (2002) Du train à vapeur au TGV: Sociologie du travail 768 d'organisation (Paris: Presses Universitaires de France)

769 Thévenot, L. (1984) Rules and implements: Investment in forms. Social Science Information $77023(1)$ pp. $1-45$

771 Tregear, A. (2011) Progressing knowledge in alternative and local food networks: Critical 772 reflections and a research agenda. Journal of rural studies 27 (4) pp. 419-430

773 van der Ploeg, J.D., H. Renting, G. Brunori, K. Knickel, J. Mannion, T. Marsden, K. De 774 Roest, E. Sevilla-Guzmán and F. Ventura (2000) Rural development: From practices and 775 policies towards theory. Sociologia Ruralis 40 (4) pp. 391-408

776 Wald, N. (2015) Towards utopias of prefigurative politics and food sovereignty: Experiences 777 of politicised peasant food production. Pp. 107-125 in P.V. Stock, M. Carolan, C. Rosin, eds., 778 Food utopias. Reimagining citizenship, ethics and community (London \& New York: 779 Routledge)

780 Watts, D., B. Ilbery and D. Maye (2005) Making reconnections in agro-food geography: 781 Alternative systems of food provision. Progress in Human Geography 29 (1) pp. 22-40

782 Weatherell, C., A. Tregear and J. Allinson (2003) In search of the concerned consumer: UK 783 public perceptions of food, farming and buying local. Journal of rural studies 19 (2) pp. 233$784 \quad 244$

785 Whatmore, S. and L. Thorne (1997) Nourishing networks: Alternative geographies of food. 786 Pp. 287-304 in D. Goodman and M. Watts eds., Globalising food: Agrarian questions and 787 global restructuring (New York: Routledge)

\footnotetext{
${ }^{\mathrm{i}}$ There are differences between the sociology of organised action and ANT. Some debates have even pitted some of their leading authors against each other. Friedberg (1997) notably challenged the human-non-human symmetry specific to ANT. Latour (2005), for his part, argued that Friedberg's joint analysis of the strategies of actors and the rules of systems fails, like many others, to give an adequate understanding of the social. According to Latour, collective action is the property of heterogeneous actor-networks, while Friedberg emphasises the constitution of "local orders", i.e. stable interaction patterns. However, these differences
} 
should not hide strong convergences. The sociology of organised action and ANT share an endogenous explanation for the constitution of collective action (nothing is explained by exogenous forces) and recognition of the importance of rules and material devices.

ii In 2016, the federation Artisans du Monde was composed of 132 associations from all over France. The main activity of these associations is to man points of sale proposing food products and handicrafts that come exclusively from fair trade networks. To that end, rather than buying directly from producers' groups, they put in their orders with their central purchasing office, Solidar'Monde, and other operators. The local groups also conduct educational actions and do advocacy work with the help of the tools that the federation develops.

iii Fairtrade International was founded in 1997 by seventeen "national initiatives" (Fairtrade UK, Max Havelaar France, etc.) with the aim of coordinating their activities. In 2016 it federated twenty-five national initiatives and three certified producers' organisations from Africa, Latin America, and Asia-Oceania. Its main action consists of drawing up and constantly revising the existing Fairtrade fair trade standards for some fifteen product families. Sales of products bearing the Fairtrade logo amounted to some 7.88 billion euros in 2016 (Fairtrade international, Annual report 2016-2017, 2017).

${ }^{\text {iv }}$ Coordinadora Latinoamericana y del caribe de pequenos productores de commercio justo 